\title{
Gorbeialdeko Hondakinen Partzuergoak kudeatutako hiri-hondakin solidoen errefusaren karakterizazioa
}

\author{
(Characterization of the mixed urban solid waste fraction \\ managed by the consortium of Gorbea Foothills in Alava)
}

\author{
Daniel Zuazagoitia1*, Naiara Rojo², Arrate Santaolalla ${ }^{2}$, \\ Iñigo Zuazagoitia ${ }^{3}$ \\ ${ }^{1}$ Matematika eta Zientzia Esperimentalen Didaktika Saila, \\ Hezkuntza eta Kirol Fakultatea (UPV/EHU) \\ ${ }^{2}$ Ingeniaritza Kimikoa eta Ingurumenaren Ingeniaritza Saila, \\ Gasteizko Ingeniaritzako Unibertsitate Eskola (UPV/EHU) \\ ${ }^{3}$ Gasteizko Ingurugiro Gaietarako Ikastegia \\ *daniel.zuazagoitia@ehu.eus
}

DOI: $10.1387 /$ ekaia.19068

Laburpena: Ikerketa-lan honetan Arabako Gorbeialdeako Hondakinen Partzuergoak kudeatzen dituen hiri-hondakin solidoen (HHSen) errefusa frakzioa karakterizatzeko proposaturiko metodologia eta lorturiko emaitza nagusiak jaso dira. Aztertu diren laginak osatzeko, bilketa kamioiek egin beharreko ibilbideak diseinatu dira, eta horretarako aldagai orokor bi kontuan hartu dira: sasoia (negua eta uda) eta etxebizitza-mota (herrialdea, baserrialdea eta txaletak). Egindako analisiek adierazi dute bi aldagai horiek eragina dutela errefusa frakzioaren konposizioan, eta batez ere errefusa osatzen duten bi frakzio nagusietan: materia organikoa eta bestelako hondakinak. Nabarmentzekoa da errefus masa totalaren \%65 (gutxi gorabehera) birzikla edota berrerabil daitezkeen materialek osatzen dutela. Oro har, aztertutako lagin guztiek hobetzeko hein zabala dute materia organikoaren bilketa selektiboan.

Hitz gakoak: hiri-hondakin solidoak, errefusaren karakterizazioa, estratifikazioa, laginketa, laginaren aurretratamendua.

Abstract: The following research work includes the proposed methodology and the results obtained for the characterization of the mixed waste fraction of the urban solid waste managed by the consortium of Gorbea Foothills in Alava. In order to conform 
the samples of urban waste analysed, the routes to be carried out by the trucks were designed, and for these two variables were taken into account: the season (winter and summer) and the area (urban, rural or chalets origin). The analyses carried out show that these two variables have an effect on the composition of the mixed waste fraction, especially on the two major fractions: organic matter and other residues. Within the fraction analysed, more or less $65 \%$ of the waste could be recycled or reused. In general, all the samples analysed show a great improvement margin in terms of selective collection of organic matter.

Keywords: municipal solid waste, mixed fraction characterization, stratification, sampling, sample pretreatment.

\section{SARRERA}

Gizartea garatu den heinean, kontsumo-patroiak erabat aldatu dira. Gaur egun, gure ekonomia ekoizpen- eta kontsumo-sistema linealean oinarrituta dago (baliabideak ustiatu, eraiki edo fabrikatu, kontsumitu, erabili eta suntsitu); eredu horrek datozen belaunaldien etorkizuna kolokan jartzen du muga planetarioetara hurbiltzen garen neurrian [1]. Sistema horren ondorioz, hondakinen sorkuntza modu esponentzialean handitu da azken urteotan, eta hiri-hondakin solidoen (HHSen) kudeaketa kezka handiko gaia bihurtu da.

HHSen prebentzioa, kudeaketa eta tratamendu zuzena erabat beharrezkoak dira horiek ekosistemetan, biodibertsitatean eta giza osasunean dituzten eragin negatiboak ekiditeko. Hori dela eta, Europan, Espainian bai eta Euskal Autonomia Erkidegoan (EAEn) ere HHSen kudeaketa eta tratamendu egokia bermatzen duten hainbat lege eta plan garatu dira. Gaur egun indarrean dauden zuzentarauen, legeen eta planen [2-4] ardatz nagusiak honako hauek dira: hierarkia-printzipioa bultzatzea, hondakinen sorrera murriztea, HHSen birziklatzea sustatzea, eta hondakindegira eramaten den HHSen kopurua murriztea. Europan indarrean dagoen zuzentarauan [2] finkatutako helburuak zorroztea proposatu da berriki; horren arabera, 2035rako HHSen $\% 65$ birziklatu, ontzien $\% 75$ birziklatu, eta hondakin guztien isurketa zabortegietan \%10ra murriztu beharko dira. Argi dago, beraz, egungo erronka HHSen kantitatea murriztea eta horien bereizketa egokia egitea dela.

Araban HHSei loturiko zerbitzuak Koadrilek, Udaletxeek eta Arabako Foru Aldundiak (AFAk) hartzen dituzte beren gain. Hondakin horien kudeaketa modu publikoan edota pribatuan egiten da, AFAren Arabako Plan Orokorrean (2006-2016) jasotakoari jarraituz. Gorbeialdeko Koadrila da Arabako zazpi Koadriletako bat, eta Aramaio, Arrazua-Ubarrundia, Legutio, Urkabustaiz, Zigoitia eta Zuiako udalerriek osatzen dute (azalera $=494 \mathrm{~km}^{2}$, biztanleak $=9.620$ ). Han, HHSak osatzen dituzten honako 
frakzio hauek modu selektiboan biltzen dira: ontzi arinak, papera eta kartoia, beira, errefusa, inausketak eta lorezaintzako hondakinak, olioa, pilak, puntu berde mugikorrean jasotako hondakinak, landa puntu berdean jasotako hondakinak, tamaina handiko hondakinak, eta beste hondakin batzuk (arropa/telefono mugikorrak/liburuak...). Frakzio horietatik, Gorbeialdeko Hondakinen Partzuergoak Urkabustaiz, Zuia, Zigoitia, Legutio, Otxandio eta Oletako kontzejuko errefusa, ontzi arinak eta hondakin handiak kudeatzen ditu, eta beste guztiak, berriz, AFAk.

Indarrean dagoen 22/2011 legearen arabera, EAEn 2020. urterako HHSen $\% 50$ birziklatu, eta 2010. urtean sortutako hondakinen kantitatea $\% 10$ gutxitu behar da [5]. Baina, betetzen al dira legez ezarritako helburu horiek? Hondakin sorreraren murrizketari dagokionez, 2011-2016 bosturtekoan Gorbeialdeko Koadrilako HHSen sortze-maila \%4an murriztu zen. HHSen bereizketa eta birziklatze egokiari dagokionez, Gorbeialdeko Koadrilan 5.274.069 kg HHS jaso ziren 2016an; hau da, biztanle bakoitzak $546 \mathrm{~kg}$ HHS sortu zituen urte horretan, Arabako batez bestekoa baino $128 \mathrm{~kg}$ gehiago urtero (Araban $418 \mathrm{~kg} /$ (biz. urte) sortu ziren 2016an, batez beste). Tasa horretatik $-546 \mathrm{~kg} \mathrm{HHS}$ ((biz-urte) $-358 \mathrm{~kg}$ errefusari dagozkio; Arabako batez bestekoarekin konparatuz, $287 \mathrm{~kg}$ errefus/(biz·urte), balio hori nahiko altua da. Ezbairik gabe, beraz, Partzuergoak kudeatzen dituen hiru frakzioetatik (errefusa, ontzi arinak eta hondakin handiak) errefusa da HHSen frakziorik ugariena: sortutako hondakinen ia bi heren (\%66, gutxi gorabehera) errefusari dagozkio [6].

Argi dago, beraz, bilketa selektiboaren ehunekoa (2016. urtean jasotako masa osoaren \%34,5) eta HHSen sorreraren murrizketa urruti gelditzen direla 22/2011 legeak eta EAEko Prebentzio eta Hondakinen Kudeaketa Planak 2020 ezartzen dituzten helburuetatik [3, 5]. Horiek lortzeko bidea jatorrian HHSen gaikako bereizketa egokia egitea da. Horretaz gain, errefus-masaren murrizketak onura ekonomikoa ekarriko lioke Partzuergoari, bi bidetatik: 1) tratamendu-plantari gutxiago ordaindu beharko lioke (errefus-masa gutxiago sortuko zelako), eta 2) birziklatzaileek gehiago ordainduko liokete bereizita bildutako hondakinengatik.

Hortaz, Gorbeialdeko Hondakinen Partzuergoak egindako esfortzuek errefus-masaren murrizketa eta kudeaketa egokia izan behar dute helburu. Izan ere, birziklagarriak diren hondakin asko biltzen dira bereiztu gabe errefusa frakzioan. Adibide bat emateko, Arabako Koadriletan egindako HHSen errefusaren azken ezaugarritzearen arabera (2011. urtekoa eta Foru Aldundiaren hondakinen behatokiak urteroko txostenean jasotzen duena), frakzio horren \%92,1 material berreskuragarriz osatuta dago [6].

Gaur egun ez da zehazki ezagutzen Gorbeialdeko Hondakinen Partzuergoak kudeatzen duen errefusaren konposizio zehatza. Hala ere, beharrezkoa da frakzio horren konposizioa ezagutzea gaikako bilketa indartu eta 
gaizki bereizten diren frakzioak detektatu ahal izateko; hau da, errefusaren zein portzentaje dagokien hondakin birziklagarriei, eta zein diren hondakin horiek. Modu horretan bakarrik diseinatu ahal izango dira arazoari aurre egiteko jarduera zehatzak [7-9].

HHSen karakterizazioa egiteko, gomendagarria da aldez aurretik estratifikazioa egitea [9], hau da, aztertuko diren hondakinak beren konposizioan eragina izan dezaketen parametroen arabera sailkatzea. Adibidez, jatorriak hondakinen konposizioan eragin handia izango du: osaera aldatuko da horien jatorria etxekoa, komertziala edota industriala bada. HHSen (oro har eta errefusaren bereziki) konposizioaren kasuan, eragina izan dezaketen faktoreen artean [10-12] garrantzitsuenetarikoak 1. taulan bildu dira.

1. taula. HHSen konposizioan eragina duen hainbat faktore.

\begin{tabular}{c|l}
\hline Etxebizitza-egitura & $\begin{array}{l}\text { Etxebizitza-egiturak (landaguneak edo baserrialdeak, hirialdeak, } \\
\text { trantsizioguneak, etxe isolatuak edo pisu askotako eraikinak) eragina } \\
\text { du hondakinen konposizioan. }\end{array}$ \\
\hline $\begin{array}{c}\text { Urte-sasoia edo } \\
\text { urtaroa }\end{array}$ & $\begin{array}{l}\text { Hondakinen konposizioa urtaroaren arabera alda daiteke, konposi- } \\
\text { zioari eta kantitateari dagokienez. Komenigarria da karakterizazioa } \\
\text { urteko bi urtarotan egitea, gutxienez. }\end{array}$ \\
\hline $\begin{array}{c}\text { Bilketa-sistema } \\
\text { Bilketa-eguna } \\
\text { Gaikako bilketak hondakinen konposizioan eragin handia du; hau } \\
\text { lak gaika biltzen diren toki baten eta gaika biltzen ez diren beste ba- } \\
\text { ten HHSen konposizioaren artean. }\end{array}$ \\
\hline $\begin{array}{l}\text { Edukiontzien } \\
\text { tamaina }\end{array}$ & $\begin{array}{l}\text { Edukiontziaren tamainak eta motak, bai eta bilketa egiten duten ka- } \\
\text { astegunetan zehar. } \\
\text { mioi motak ere, eragina izan dezake HHSen osaeran. }\end{array}$ \\
\hline $\begin{array}{c}\text { Kontzientziazioa } \\
\text { eta alderdi }\end{array}$ & $\begin{array}{l}\text { Alderdi sozio-ekonomikoek eta kulturalek eragin handia dute HHSen } \\
\text { konposizioan. Tokian tokiko politikak. Tasak, pizgarriak, etab. }\end{array}$ \\
\hline sozio-ekonomikoa
\end{tabular}

Lan honen helburua Gorbeialdeko Hondakinen Partzuergoak kudeatzen dituen HHSen errefusaren karakterizazioa egitea izan da, hori ezagututa Partzuergoak legez ezarritako birziklatze-tasak lortzea ahalbidetuko duten jarduerak proposa ditzan. Horretarako, bi estratifikazio-parametro aukeratu dira (etxebizitza-egitura eta urtaroa), laginketa metodologia planteatu da, eta hondakinen osaera (masa-portzentajean) kalkulatu da. 


\section{METODOLOGIA}

Ikerketa-lan honetan erabili den metodologia ondoko azpiatal hauetan deskribatu da: ikerketa-eremuaren estratifikazioa egiteko jarraitu diren irizpideak, laginketa egiteko erabili diren ibilbideen diseinua, eta laginaren aurretratamenduan eta haren karakterizazioan jarraitu den metodologia.

\subsection{Ikerketa-eremuaren estratifikazioa}

Gorbeialdeko Hondakinen Partzuergoak kudeatzen duen HHSen errefusaren karakterizazioa egiteko, honako estratifikazio-parametro hauek aukeratu ziren [9]:

\subsubsection{Etxebizitza-egitura}

Aurretik azaldu bezala, Gorbeialdeko Hondakinen Partzuergoak Urkabustaiz, Zuia, Zigoitia, Legutio, Otxandio eta Oletako kontzejuko errefusa kudeatzen du, besteak beste. Udalerri horiek Gorbeialdeko Koadrilan kokatzen dira (Otxandio izan ezik), eta Koadrila horretan hiru etxebizitza-multzo mota nagusi bereizten dira:

- Landa-eremua edo baserrialdea: baserriek osatzen dute, gehienbat (Kuadrilako biztanlegoaren $\% 35$ baserrialdean bizi dela zenbatetsi da [13]).

- Biztanle gune handiak (herrialdea): Murgia (1.158 biz.), Legutio (1.365 biz.), Otxandio (1.295 biz.), Izarra (947 biz.) eta Gopegi-Ondategi (434 biz.)

- Txaletak: Koadrilan aisialdirako badira zenbait eremu (UribarriGanboa eta Urrunagako urtegiak, adibidez), zeintzuetan lorategia duten bigarren etxebizitzak kokatzen diren.

Ikerketa-esparrua, beraz, hiru eremuetan banatu zen, etxebizitzen egituraren arabera: baserrialdea (edo landa-eremua), herrialdeak (gune handiak) eta txaletak.

\subsubsection{Urte-sasoia edo urtaroa}

Aukeratutako eremu bakoitzeko (baserrialdea, herrialdea eta txaletak) errefusaren bi karakterizazio egin ziren: bata neguan (otsailean) eta bestea udan (ekainean). Beraz, guztira, sei karakterizazio egin ziren: hiru neguan, bat eremu bakoitzeko, eta beste hiru udan. 


\subsection{Errefusaren laginketa: ibilbideen diseinua eta errefusaren bilketa}

Aukeratutako hiru eremuetan (baserrialdean, herrialdean eta txaleteningurunean) jasotako errefusaren laginketa egiteko, ibilbide bana diseinatu zen. Horretarako, lehenik eta behin, Gorbeialdeko Hondakinen Partzuergoaren jarduera-eremuan errefusa jasotzen duten edukiontzien (edukiontzi grisaren) zenbaketa egin zen. Ondoren, edukiontziak aukeratutako hiru etxebizitza-egituraren arabera sailkatu, zerrendatu eta mapan kokatu ziren. Azkenik, edukiontzi-zerrenda bakoitzetik ausaz 30-35 ontzi aukeratu ziren, ahalik eta lagin adierazgarriena lortzeko.

Diseinatutako hiru ibilbideak errefusa bildu eta garraiatzen duen enpresari (ESCORi) jakinarazi zitzaizkion. Adostutako laginketa-egunetan (guztira sei egun), kamioi batek zerrendako edukiontzietan zegoen errefusa jaso eta kudeaketa-plantara eraman zuen han analisia burutzeko.

\subsection{Laginaren aurretratamendua}

Argitaratuta dagoen bibliografian oinarrituta, laginketa-egun bakoitzean kamioiak kudeaketa-plantara eramandako lagina aurretratatu zen, karakterizatu beharreko hondakin-kantitatea 250 kg-ra (gutxi gorabehera) murrizteko [10]. Ezer baino lehen, kamioiak jasotako hondakinak porlanezko zabalgune baten gainean utzi ziren (1.000-1.200 kg) eta, hondeamakina baten laguntzaz, sakabanatu, nahastu eta homogeneizatu ziren. Jarraian lagina laurdenkatu zen, hau da, jasotako masa totala lau laurdenetan banatu, eta ausaz aurkako bi laurden aukeratu ziren; horrela $500 \mathrm{~kg}$ inguruko masako azpilagina lortu zen. Ondoren, artean itxita zeuden poltsak artaziz ireki ziren, azpilagina hondeamakinarekin homogeneizatu zen, eta berriro laurdenkatu zen. Kasu honetan, lortutako laurden bakoitzetik $50 \mathrm{~kg}$ hartu ziren, eta, ondoren, ausaz aukeratutako aurkako bi laurdenetatik beste $25 \mathrm{~kg}$. Bukaeran, jasotako etxebizitza-eremu lagin bakoitzeko adierazgarriak ziren 250 kg-ko azpilagina lortu zen karakterizazioa egiteko. Laginaren aurretratamenduaren eskema 1. irudian jaso da.

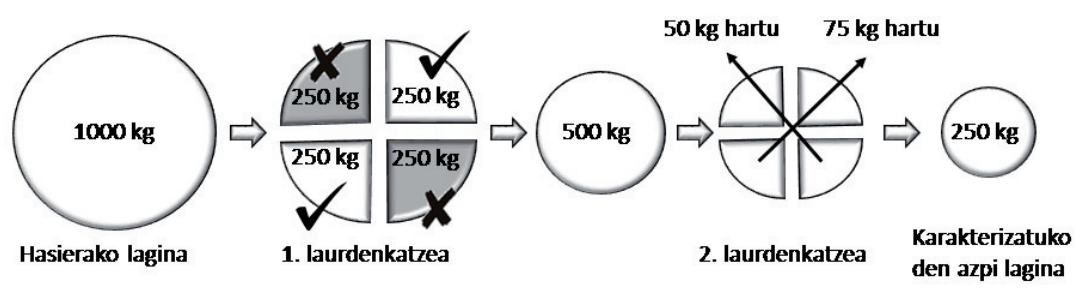

1. irudia. Laginaren aurretratamendua: karakterizatuko den azpilagina lortzeko prozedura. 


\subsection{Errefusaren karakterizazioa}

Errefusaren karakterizazioa egiteko, 250 kg-ko azpilagina esku-palen laguntzaz mahai baten gainean jarri zen, eta horretan zeuden hondakinmota ezberdinak begi bistaz identifikatu eta eskuz bereiztu ziren [10]. Hondakin-mota bakoitzeko multzo bat egin zen, eta horren masa neurtu zen (22 kg-ko Tolsen esku-dinamometroaren bidez). Azkenik, karakterizatutako masa totalaren konposizioa kalkulatu zen, masa-portzentajean. Horretarako, ekuazio hau erabili zen:

Frakzioa, $\%$ masan $=$ hondakin-mota jakin baten masa $* 100 /$ azpilaginaren masa osoa

Bereiztutako hondakin frakzioak honako hauek izan ziren: beira (botilak eta potoak), papera eta kartoia (egunkariak, aldizkariak, kutxak eta antzekoak), ontzi arinak (ontzi metalikoak, brik-ontziak, plastikozko ontziak, filma, aluminio-papera eta antzekoak), materia organikoa (elikagai-soberakinak, kimatze eta sega-hondakinak eta antzekoak), eta bestelako-hondakinak. Azken frakzio horren honako osagai hauek ere bereiztu ziren: arropak/ehunak/zapatak, nekazaritzan erabilitako plastiko handiak eta pixoihalak.

\section{EMAITZAK}

\subsection{Ibilbideen diseinua eta errefusaren bilketa}

Guztira 368 edukiontzi zenbatu ziren: 59 Urkabustaizen, 130 Zuian, 80 Zigoitian, 56 Legution eta 43 Otxandion. Aukeratutako hiru etxebizitzaegituren arabera, horietatik 208 edukiontzi landagunean daude, 101 hirigunean eta 59 txaleten gunean.

Datuak kontuan hartuta, honako ibilbide hauek diseinatu ziren:

a) lehen ibilbideak herrigune handienak hartu zituen: Izarra, Legutio, Murgia eta Otxandio. Eremu horretan 32 edukiontzi jaso ziren guztira (2. irudia).

b) Bigarren ibilbideak landaguneak hartu zituen (baserrialdea). Eremu horretan 31 edukiontzi jaso ziren laginketan: 6 Urkabustaizen, 7 Zuian, 7 Zigoitian, 8 Legution eta 3 Otxandion.

c) Hirugarren ibilbideak txaleten guneak hartu zituen. Guztira 38 edukiontzi jaso ziren eremu honetan: 10 Murgian, 5 Otxandion, 8 Izarran, 8 Zigoitian eta 7 Legution (3. irudia).

Ibilbide bakoitzean kamioiak $1200 \mathrm{~kg}$ hondakin inguru jaso zuen. 


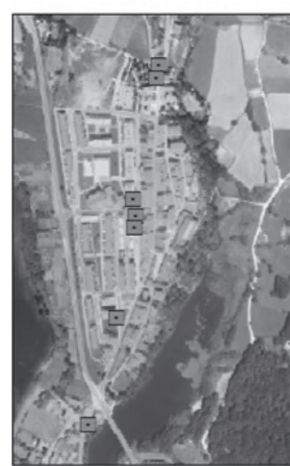

Legutio: 7 edukiontzi

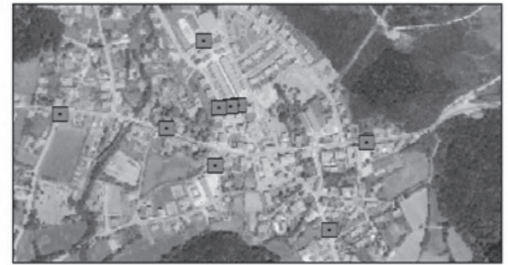

Murgia: 8 edukiontzi

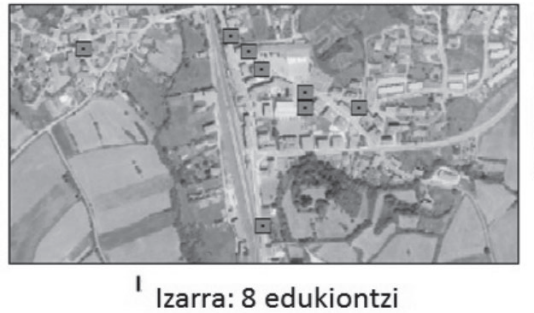

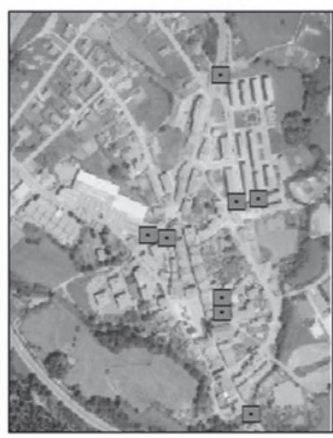

Otxandio: 8 edukiontzi

2. irudia. 1.go ibilbidea; hirigunea. Karratuek jasotako edukiontziak adierazten dituzte.

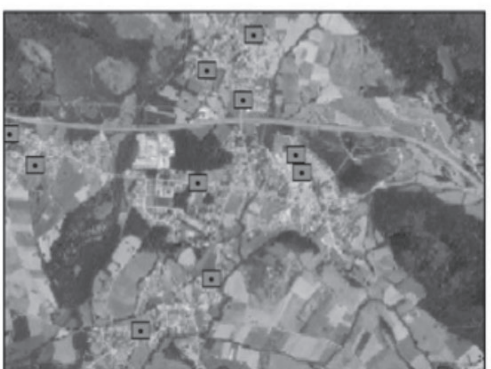

Murgia: 10 edukiontzi

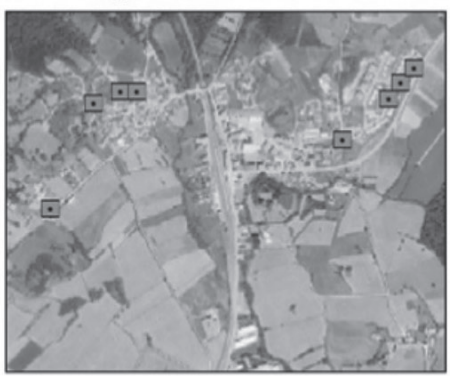

Izarra: 8 edukiontzi

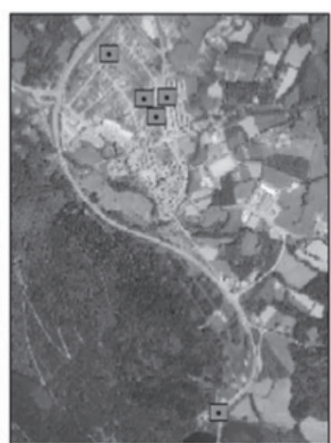

Otxandio: 5 edukiontzi

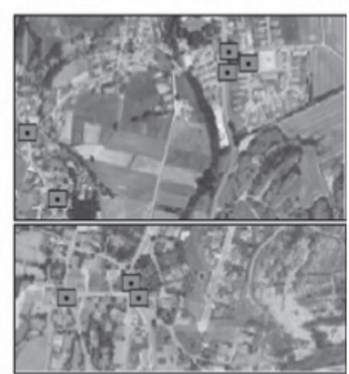

Zigoitia: 8 edukiontzi

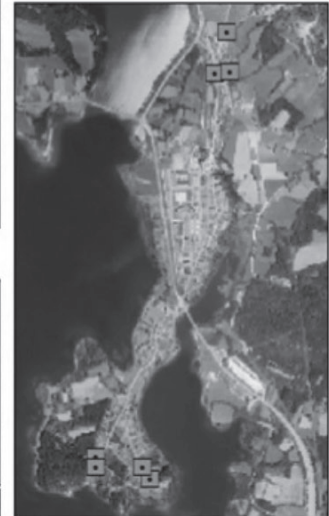

Legutio: 7 edukiontzi

3. irudia. 3. ibilbidea: txaleten ingurunea. Karratuek jasotako edukiontziak adierazten dituzte. 


\subsection{Karakterizazioa}

Guztira sei laginketa ezberdinen karakterizazioak egin ziren, bi urtarotan eta hiru eremu ezberdinetan. Errefusaren karakterizazioan hondakinak bost frakziotan bereiztu ziren.

\subsubsection{Batez besteko karakterizazioa}

Karakterizatutako errefusaren batez besteko konposizioa 4. irudian jaso da (lagin guztiak kontuan hartuta). Argi ikusten denez, materia organiko biodegradagarria errefusaren osagai nagusia da, eta horrek karakterizatutako hondakin-masaren \%48,7 hartu zuen. Bestelako-hondakinek masa totalaren \%35 osatu zuten, ontzi birziklagarriek \%7,2, paperak eta kartoiak \%6,8 eta, azkenik, beirak \%2,1. Beraz, Gorbeialdeko Hondakinen Partzuergoak HHSen errefus bezala biltzen eta kudeatzen dituen hondakinen $\% 65$ elementu birziklagarriak edota berrerabilgarriak dira.

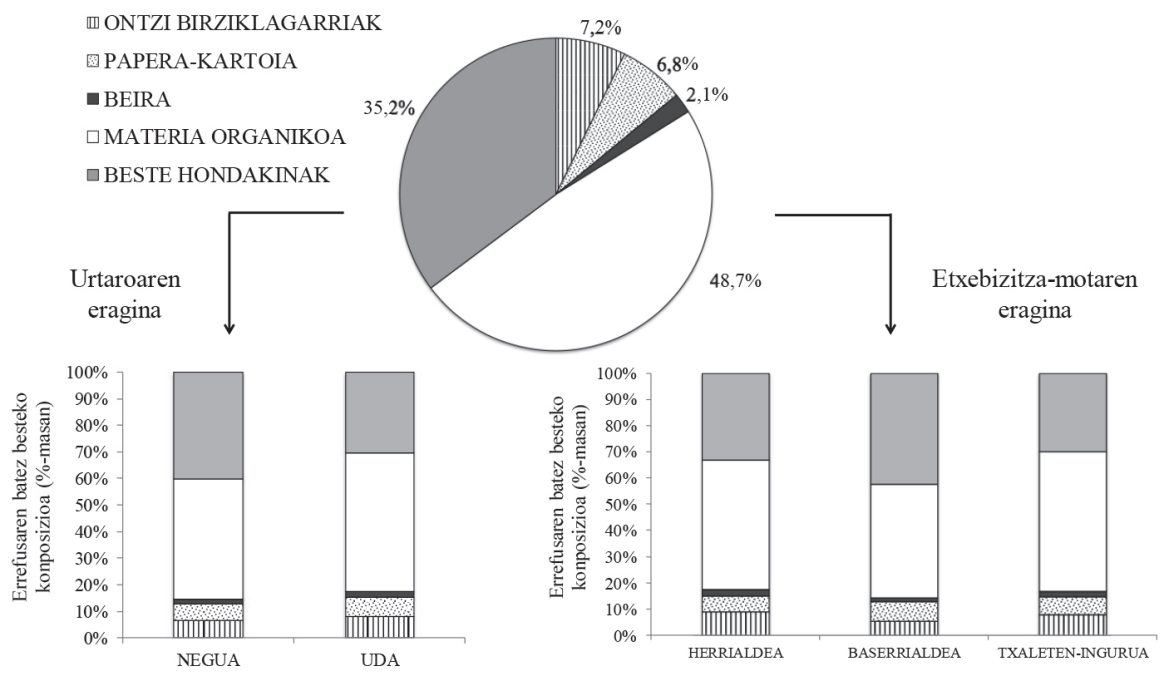

4. irudia. Hiri-hondakin solidoen errefusaren batez besteko karakterizazioa (goian); sasoiaren (behean ezkerrean) eta eremuen (behean eskuman) eragina batez besteko osaeran (masa hezea, \%).

Urtaroak eta etxebizitza-motak eragina dute HHSen errefusaren batez besteko konposizioan, materia organiko biodegradagarriari eta bestelako-hondakinei dagozkien portzentajetan, batez ere. Udan, bestelako-hondakinen frakzioa ez ezik, beste frakzio guztien portzentajeek ere gora egin zuten (4. 
irudia). Etxebizitza-egituraren eraginari dagokionez, txaleten eremuan jasotako hondakinek materia organiko biodegradagarriaren portzentaje handiena aurkeztu dute $(\% 53,3)$, beste zonetan karakterizatutako hondakinekin alderatuz (\%49,5 herrialdean eta $\% 43,2$ baserrialdean). Baserrialdeko laginetan, aldiz, bestelako-hondakinen proportziorik handiena bereiztu da $(\% 42,5)$, eta beira eta ontzi birziklagarrien portzentajea baxuena izan da (\%1,6 eta $\% 5,3$, hurrenez hurren).

Arabako eskualdeetan jasotako HHSen errefusaren batez besteko konposizioa (2011n) eta ikerketa-lan honetan lortutako datuak (2017) 5. irudian irudikatu dira [4]. Ikus daitekeen bezala, materia organiko biodegradagarriaren portzentajea oso antzekoa da bi kasuetan: $\% 49$ eta $\% 47$, hurrenez hurren. Bestelako-hondakinen portzentajea, aldiz, 3,5 aldiz handiagoa da Gorbeiako Hondakinen Partzuergoak kudeatzen duen errefusaren kasuan, Arabako batez bestekoarekin konparatuz. Desberdintasun horrek, jakina, beste frakzioen (ontzi birziklagarrien, paperaren eta kartoiaren, eta beiraren) masa-portzentajean eragina du: lan honetan lortutako emaitzen arabera, frakzio horien batez besteko masa-portzentajeak Arabakoak baino baxuagoak dira modu adierazgarrian.

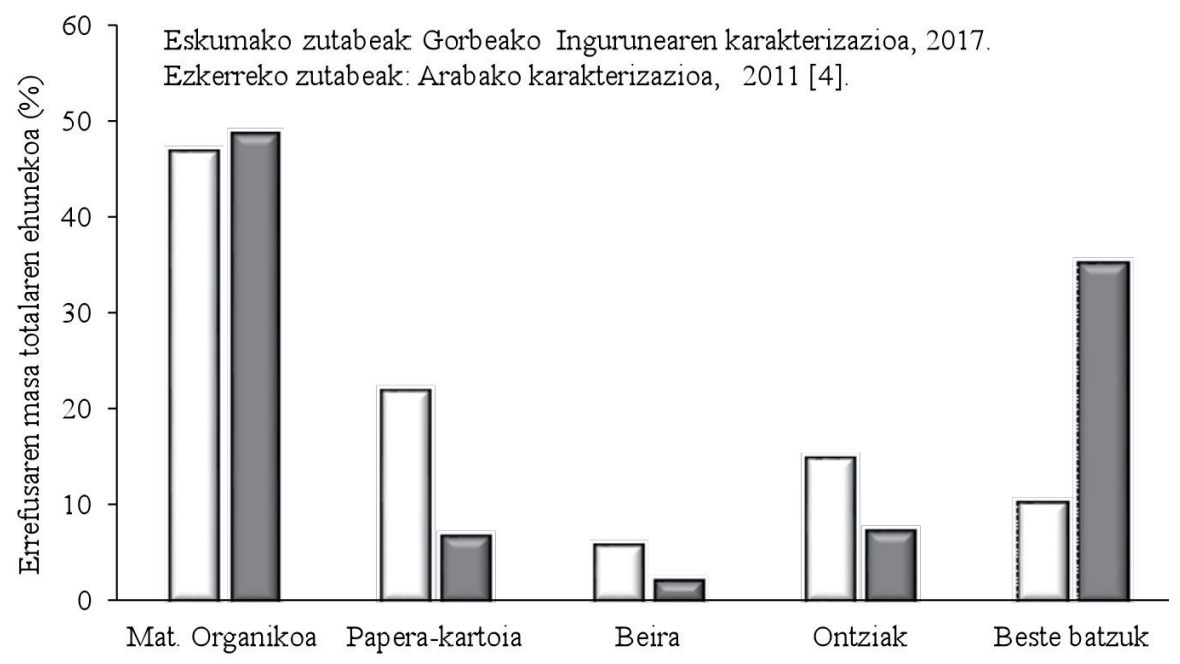

5. irudia. Gorbeialdeko Hondakinen Partzuergoak (eskumako zutabeak) kudeatzen duen errefusaren (2017. urtean) eta Arabako hiri-hondakinen (ezkerreko zutabeak) errefusaren batez besteko konposizioen (2011. urtean) arteko konparazioa. Oharra: Arabako Lurralde Historikoaren Hiri-Hondakinen Inbentarioan (2017) bildutako datuak moldatu dira, ikerketa-lan honetan bereiztutako frakzioen datuekin alderatu ahal izateko. 


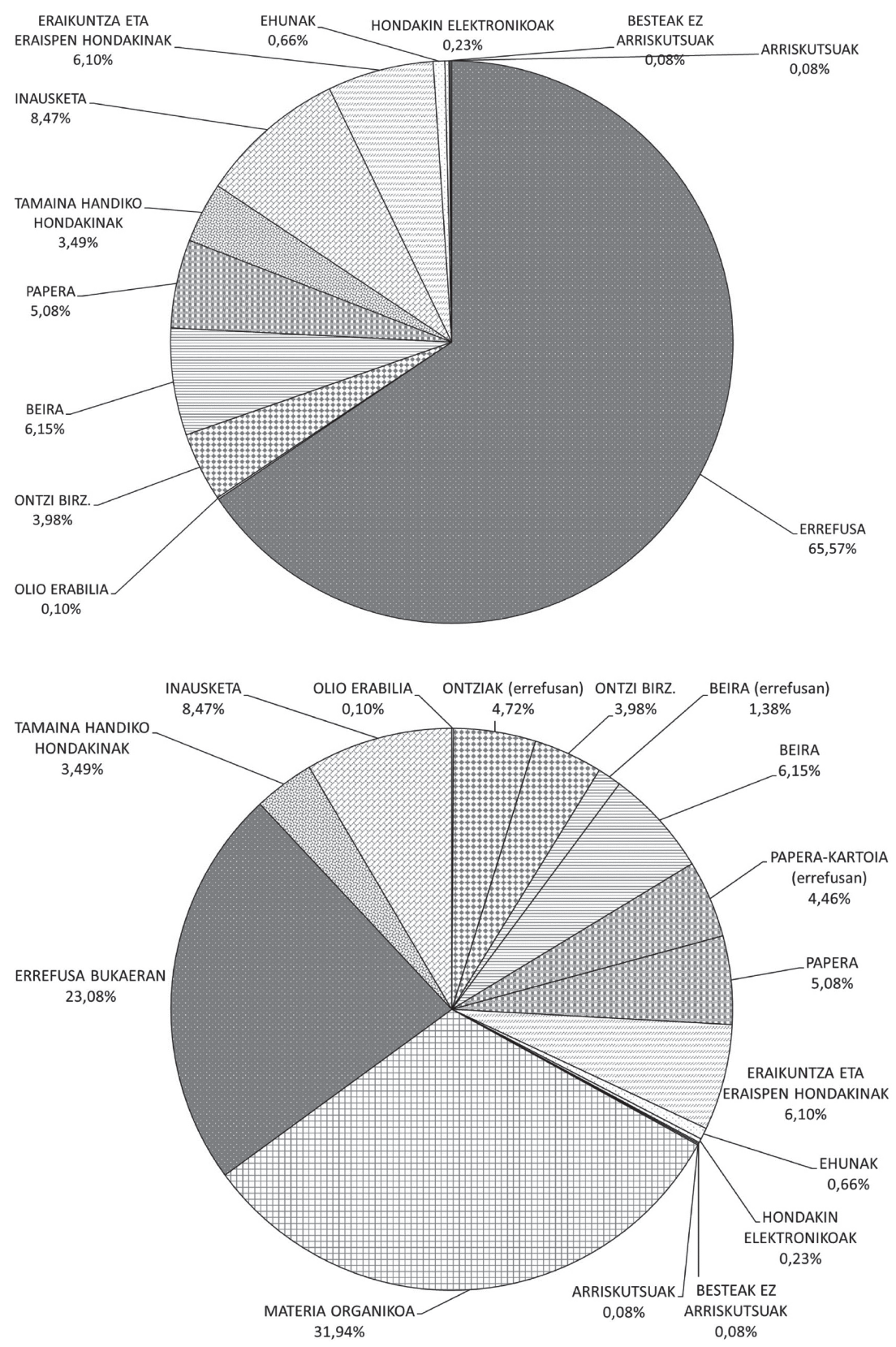

6. irudia. HHSen konposizioa, ikerketa-lan honetan egin den errefusaren karakterizazioa kontuan hartuz; goian: Gorbeialdeko Koadrilako HHSen konposizioa (2016); behean: HSSen konposizioa materia organiko biodegradagarria, papera eta kartoia, beira eta ontzi birziklagarriak guztiz bereiztuko balira jatorrian. 
Errefusaren karakterizazioan lortutako beira, ontzi birziklagarri eta paper eta kartoi frakzioen masa-portzentaje baxuak lurralde honetan gaikako bilketaren eraginkortasunaren adierazle dira. Azpimarratzekoa da beiraren masa-portzentajea baxuena izan zela karakterizatutako errefusean (beste frakzioekin konparatuz). Beiraren bilketa bereiztua eraginkortasun handiko zabor-bilketako zerbitzua da, eta, gainera, gora egin du azken hamarkadan (azken bi urteetan izan ezik), Arabako Lurralde Historikoaren Hiri-Hondakinen Inbentarioan jasotako datuen arabera [6].

Karakterizaturiko errefusa osatu zuten materia organiko biodegradagarria, papera eta kartoia, beira eta ontzi arinak jatorrian modu selektiboan bereizi izan balira, kudeatu beharreko errefus-masa nabarmenki murriztuko litzateke. Aipatzekoa da materia organiko biodegradagarriaren bereizketa egokiak kudeatu beharreko masa totalaren murrizketan izango lukeen eragina, hori baita errefusaren erdia (gutxi gorabehera). Gorbeialdeko Koadrilako HHSen konposizioa oinarri hartuz [6], errefusa HHSen masa osoaren $\% 65,57$ izatetik \%23,08 izatera pasako litzateke adierazitako lau frakzioen bereizketa modu zorrotzean egingo balitz (6. irudia).

\subsubsection{Sasoiaren eta etxebizitza-motaren eragina errefusaren konposizioan}

Eremu bakoitzean lortutako datuak aztertuz, sasoiak eta etxebizitza-motak materia organiko biodegradagarriaren eta bestelako-hondaki$n a k$ frakzioen masa-portzentajean eta horien konposizioan izan zuten eragina. Hiru eremuetan joera berdintsua izan zen (7. irudia): udan materia organiko biodegradagarriaren masa-portzentajeak gora egin zuen, eta bestelako-hondakinenak, aldiz, behera. Baserrialdeari dagozkion laginetan, ezberdintasuna nabariagoa izan zen herrialdean eta txaleten ingurunean karakterizatutakoetan baino; baliteke ezberdintasun hori hosto, lur eta indusketa-hondakinen presentzia handiaren ondorio izatea (baserrialdean beste eremuetan baino nabariagoa izan zen hondakin mota horien presentzia). 

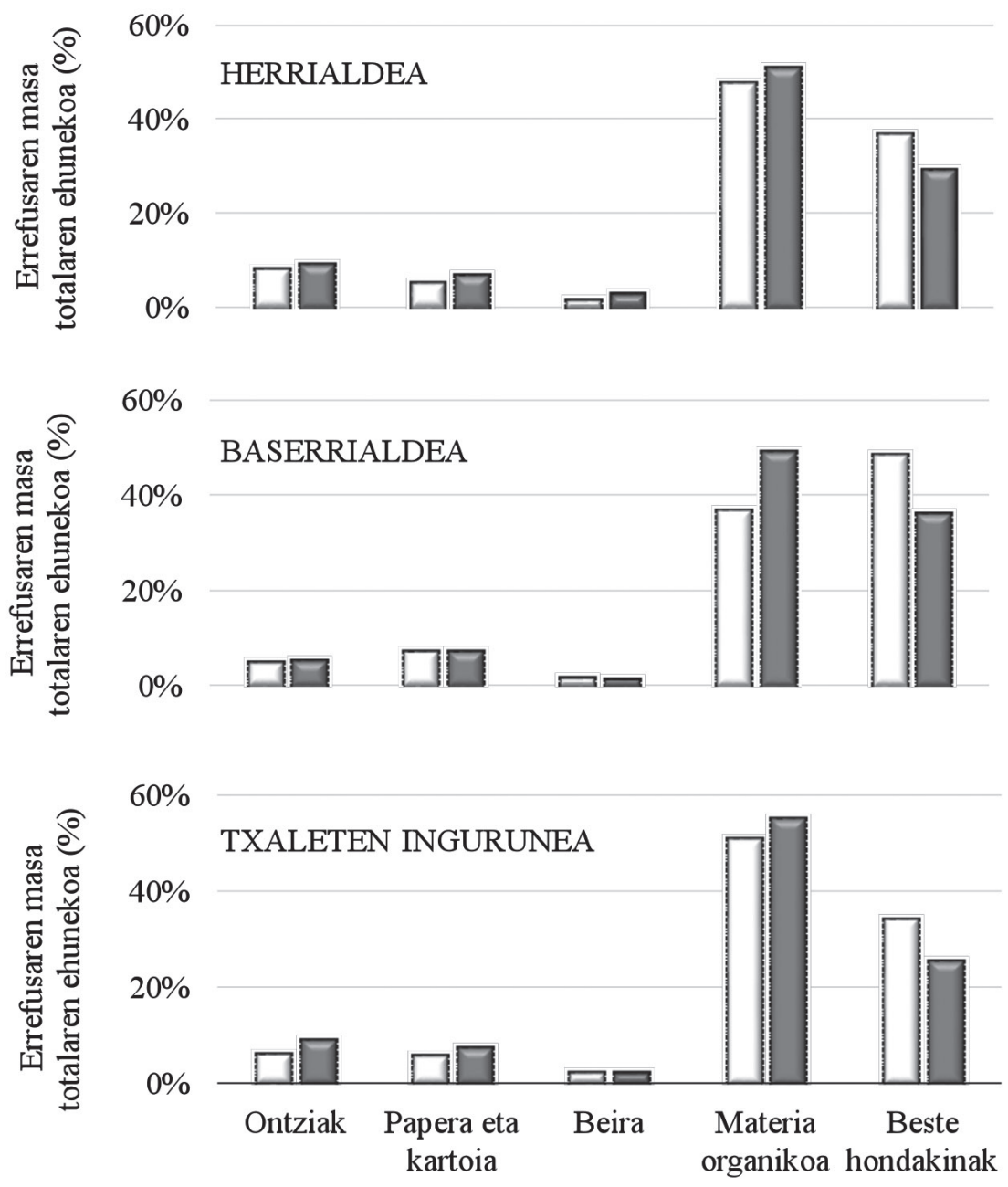

7. irudia. Errefusaren konposizioaren alderaketa, urtaroaren arabera: negua (ezkerreko zutabeak, puntuak) eta uda (eskumako zutabeak, lerro horizontalak).

Materia organiko biodegradagarriaren eta bestelako-hondakinak frakzioak osatu zuten hondakinen konposizioari dagokionez, hori eremuaren eta urtaroaren arabera nabarmenki aldatu zen. Bestelako-hondakinen konposizioa, masa-portzentajean, 2. taulan bildu da. 
2. taula. Bestelako-hondakinak frakzioaren konposizioa, masa-portzentajean (\%). Balioak beste hondakinak frakzioaren guztizkoarekiko kalkulatu da.

\begin{tabular}{l|c|c|cc|cc}
\hline \multicolumn{1}{c|}{ Eremua } & \multicolumn{2}{|c|}{ Herrigunea } & \multicolumn{2}{c|}{ Baserrialdea } & \multicolumn{2}{c}{ Txaleten Gunea } \\
\hline \multicolumn{1}{c|}{ Urtaroa } & Negua & Uda & Negua & Uda & Negua & Uda \\
\hline Ehunak/arropa & $\% 12,0$ & $\% 4,5$ & $\% 17,9$ & $\% 16,2$ & $\% 10,2$ & $\% 17,5$ \\
Pixoihal handiak & $\% 48,7$ & $\% 4,5$ & - & - & - & - \\
Plastiko handiak* & - & $\% 2,5$ & $\% 50,5$ & $\% 39,5$ & $\% 25,5$ & $\% 8,0$ \\
Besteak & $\% 39,3$ & $\% 88,5$ & $\% 31,6$ & $\% 44,3$ & $\% 64,3$ & $\% 74,5$ \\
\hline
\end{tabular}

* Frakzio honetan nekazaritzan erabiltzen diren plastiko handiak hartu dira kontuan.

Herrialdeetako laginetan, bestelako-hondakinak frakzioaren konposizioa nabari aldatu zen urtaroarekin: neguan pixoihalak (zaharren egoitzaren batean sortutakoak, karakterizatutako masa totalaren \%18) eta ehunak (karakterizatutako masa totalaren $\% 4,4$ ) izan ziren nagusi, eta udan, aldiz, askotariko materialek osatu zuten beste hondakinak frakzioa (\%1,3 bakarrik izan ziren ehunak/arropak, eta ez zen pixoihalik bereiztu). Hala ere, neguaren eta udaren arteko diferentzia hori arrazoi puntualei dagokie; nahiz eta laginketa egiteko orduan ahalik eta adierazgarritasun maila altuena lortu nahi izan, ezin dira ezagutu erabiltzaileen ohiturak eta maiztasunak. Materia organiko biodegradagarria janari-hondarrez osatua egon zen gehienbat, bi urtaroetan jasotako laginetan.

Baserrialdean, aldiz, bestelako-hondakinak frakzioan plastiko handien (normalean nekazaritzan erabiltzen direnak) masa-portzentajea adierazgarria izan zen, aztertutako bi urtaroetan (karakterizatutako masa totalaren $\% 24,6$ eta \%14,3, neguan eta udan, hurrenez hurren). Ehunen eta arropen presentzia ere nabaria izan zen, eta horiek karakterizatutako masa totalaren $\% 8,7$ eta $\% 5,9$ osatu zuten neguan eta udan, hurrenez hurren. Materia organiko biodegradagarriari dagokionez, janari-hondarrez gain inausketa-hondakinen, lurraren, eta soropilaren presentzia nabaria izan zen. Azken horiek udako laginketan negukoan baino ugariagoak izan ziren (ezin izan zen masa-portzentajea kalkulatu horiek oso nahasita zeudelako beste hondakin organikoekin).

Txaleten ingurunean bereiztutako bestelako-hondakinen konposizioan, ehunen/arropen presentzia nabaria izan zen (frakzio horren \% 10,2 eta \%17,5 neguan eta udan, hurrenez hurren). Nabarmentzekoa da neguko laginean nekazaritzan erabiltzen diren plastiko handiak agertu izana ere, masaren \%25,5. Materia organiko biodegradagarriari dagokion frakzioan, indusketa-hondakinen presentzia nabaria izan zen, udan batez ere. Hondakin horien presentziak materia organiko biodegradagarriari dagokion masa-portzentajean eragin handia izan zuen (udan karakterizatutako hondakin-masaren \%8 indusketa-hondakinek osatu zuten, materia organiko biodegradagarriaren \%14). 


\section{ONDORIOAK}

Modu ez selektiboan biltzen diren HHSen konposizioa ezagutzea ezinbestekoa da horien kudeaketa hobetzeko eta indarrean dagoen araudia betetzeko neurriak hartu nahi badira. Ikerketa-lan honetan proposatu diren laginketa- eta analisi-metodologiak Gorbeialdeko Hondakinen Partzuergoak kudeatzen duen HHSen errefusa frakzioaren karakterizazioa egitea eta horren ezaugarriak zehaztea ahalbidetu du, proposatutako hiru eremu (herriak, baserrialdeak eta txaletak) eta bi urtaroetan (negua eta uda).

Aipagarria da aztertu diren lagin guztietan materia organiko biodegradagarriaren masak osatu duela Gorbeialdeko Hondakinen Partzuergoak kudeatzen duen HHSen errefusaren portzentajerik handiena (\%49). Nahiz eta eremutik eremura desbideratze txikiak antzeman, laginketa guztietan frakzio horrek masa totalaren erdia izan du (\%43-53), gutxi gorabehera. Beirari $(\% 2,1)$, ontzi birziklagarriei $(\% 7,2)$ eta paperari eta kartoiari $(\% 6,8)$ dagozkien batez besteko portzentajeak baxuak izan dira. Azken datu honek, frakzio horien bereizketa selektiboa egokia dela mahaigaineratu du; beraz, hobekuntza-tartea frakzio horietan txikia da. Beste hondakinen frakzioak (birziklatu eta konpostatu ezin diren horiena, alegia), masa totalaren \%35 osatu dute (batez beste); horrek adierazten du Koadrilan benetan sortzen den errefus-masa dagokion kontenedorean jasotzen dena baino askoz txikiagoa dela (HHSen masa osoaren \%65,57 izatetik \%23,08ra izatera pasako litzateke bereizketa egokia izango balitz).

Emaitzetan jaso den bezala, azterturiko bi aldagaiek (urtaroa eta etxebizitza-motak) eragina dute hiri-hondakinen errefusaren konposizioan. Oro har, udan gora egiten dute materia organiko biodegradagarriaren, beiraren, paper eta kartoiaren eta ontzi birziklagarrien frakzioek. Etxebizitza-motari erreparatuz, txaleten inguruneko hondakinek materia organiko biodegradagarriaren ehunekorik handiena erakutsi dute, beste zonekin konparatuta.

\section{ESKER ONAK}

Ikerketa hau Euskal Herriko Unibertsitateak UPV/EHU zuzendutako proiektu baten barruan kokatzen da eta Euskoiker fundazioak 2016ko martxoaren 4an Gorbeialdeko Hondakinen Partzuergoari proposaturiko eta honek onartutako eskaintzaren arabera garatu da. Ikerketa-lan hau gauzatzea posible egin duen pertsona orori esker onak agertu nahi dizkiogu. 


\section{BIBLIOGRAFIA}

[1] STEFFEN, W., RICHARDSON, K., ROCKSTRÖM, J., CORNELL, S. E., FETZER, I., BENNETT, E. M., ... \& FOLKE, C. (2015). «Planetary boundaries: Guiding human development on a changing planet». Science, 347, 736-746.

[2] EUROPAKO, P. (2008). «Europako Parlamentu eta Kontseiluko 2008. urteko azaroaren $19 \mathrm{ko}$ hondakinei buruzko eta hainbat zuzentarau indargabetzen dituen 2008/98/CE zuzentaraua». Hemen Eskuragarri: https://boe.es/ buscar/doc.php?id = DOUE-L-2008-82319 (Web orrialdearen eguneratzedata: $2017 \mathrm{ko}$ abenduaren 28a).

[3] IHOBE (2015). «2020rako Hondakinak Prebenitzeko Plana». Euskadi, 2015, 218pp. Hemen Eskuragarri : http://www.euskadi.eus/web01-s2ing/eu/ contenidos/informacion/plan_residuos2020/eu_def/index.shtml (Web-orriaren eguneratze-data: $2017 \mathrm{ko}$ abenduaren $28 \mathrm{a}$ ).

[4] ARABAKO FORU ALDUNDIA (2007). «Arabako lurralde historikoan hiri-hondakinak kudeatzeko plana 2008-2016». Hemen Eskuragarri: http:// www.araba.eus/cs/Satellite?c=DPA_Plan_FA\&cid=1193046719573\& pageid=1193046468688\&pagename=DiputacionAlava\%2FDPA_Plan_ FA\%2FDPA_plan (Web-orriaren eguneratze-data: 2017ko abenduaren 28a).

[5] ESTATUKO ALDIZKARI OFIZIALA. Hondakinei eta lurzoru kutsatuei buruzko uztailaren 28ko 22/2011 Legea. Estatuko aldizkari ofiziala, 181, Espainia. Hemen Eskuragarri: http://www.boe.es/buscar/doc.php?id=BOE-A2011-13046 (Web-orriaren eguneratze-data: 2017ko abenduaren 28a).

[6] ARABAKO HONDAKINEN BEHATOKIA (2017). «2016 urteko Arabako Hiri hondakinen inbentarioa». Hemen Eskuragarri : http://www.araba.eus/ $\mathrm{cs} /$ Satellite $? \mathrm{c}=$ Page \& $\mathrm{cid}=1224001265949 \&$ pagename $=$ Diputacion Alava\%2FPage\%2FDPA_contenidoFinal (Web-orriaren eguneratze-data: 2017ko abenduaren 28a).

[7] AL-KHATIB, I. A., MONOU, M., ZAHRA, A. S. F. A., SHAHEEN, H. Q., \& KASSINOS, D. (2010). «Solid waste characterization, quantification and management practices in developing countries. A case study: Nablus district - Palestine». Journal of environmental management, 91(5), 1131-1138.

[8] GOMEZ, G., MENESES, M., BALLINAS, L., \& CASTELLS, F. (2008). «Characterization of urban solid waste in Chihuahua, Mexico». Waste Management, 28(12), 2465-2471.

[9] APPLUS NORCONTROL (2012). «Plan piloto de caracterización de residuos urbanos de origen domiciliario». Hemen Eskuragarri : http://www. mapama.gob.es/es/calidad-y-evaluacion-ambiental/publicaciones/Informe_ final_resultados_Plan_Piloto_Caracterizaci\%C3\%B3n_tcm7-277256.pdf (Web-orriaren eguneratze-data: 2017ko abenduaren 28a). 
[10] EUROPEAN COMMISION. 2004. «Methodology for the analysis of solid waste (SWA-Tool)». Hemen Eskuragarri : https://www.wien.gv.at $/ \mathrm{meu} / \mathrm{fdb} /$ pdf/swa-tool-759-ma48.pdf Web-orriaren eguneratze-data: 2017ko abenduaren 28a).

[11] GÓMEZ, G., MENESES, M., BALlinAS, L., \& CASTELLS, F. (2009). «Seasonal characterization of municipal solid waste (MSW) in the city of Chihuahua, Mexico». Waste Management, 29(7), 2018-2024.

[12] OJEDA-BENÍTEZ, S., ARMIJO-DE VEGA, C., \& MARQUEZ-MONTENEGRO, M. Y. (2008). «Household solid waste characterization by family socioeconomic profile as unit of analysis». Resources, Conservation and Recycling, 52(7), 992-999.

[13] EUSTAT, Euskal Estatistika Erakundea. http://www.eustat.eus 